\title{
The Interplay of Economics and Politics in Economic Transformations in Russia and Central Europe
}

The Society for the Advancement of SocioEconomics (S.A.S.E.) Symposium on Economic Transformations in Russia and Eastern Europe was held on Saturday, March 27, 1993 at S.A.S.E. Annual Conference, New School for Social Research, New York.

Clearly, economic transformations in Russia and Central Europe have not been going well. Main reason for their failure appears to be the economically and socially faulty conception of so-called 'Shock Therapy', with all its centrally bureaucratic, politically dogmatic and non-democratic implementation habits. A new wave of economic thought has now emerged and its representatives presented their first Central-European blueprints.

The following papers were presented at the Symposium:

1. David M. Kotz, University of Massachusetts, Amherst:

'An Alternative to Shock Therapy for Transforming the Russian Economy'

2. Allan Meltzer, Carnegie-Mellon University, Pittsburgh:

'Prices, Wages and the Sequence of Reforms'

3. Christopher Clague, IRIS, University of Maryland, College Park:

'Transition Strategies: Theory and Experience'

4. Jaroslav Vanek, Cornell University, Ithaca:

'Towards a Strategy of Democracy, Political and Economic, in Russia'

5. Vladimir Kvint, Fordham University and Arthur Andersen Co., New York:

IOS Press

Human Systems Management 12 (1993) 349-351
'Processes of Disintegration and Integration in Europe'

6. David Ellerman, The World Bank, Washington, D.C.:

'Decentralized Privatization and Management/Employee Buy-Outs'

7. Shann Turnbull, Australian Employee Ownership Association, Sydney:

'Democratic Capitalism: Self-Financing Local Ownership \& Control'

8. Eric L. Nappelbaum, Institute for Systems Analysis, Moscow, Russia:

'Economy of Shortage and Pitfalls of the Soviet Statehood'

9. Rodney C. Shrader, Georgia State University, Atlanta:

'Barriers to Entrepreneurship in Former Command Economies'

10. Alina M. Zapalska, Marshall University, Huntington, W. Va.:

'Strategic-Approach Privatization'

11. Cheryl R. Lehman, Hofstra University, Hempstead, N.Y.:

'Transforming the Economy: The Women Question in Russia'

12. Nicholas N. Kozlov, Hofstra University, Hempstead, N.Y.:

'Economic Stabilization and Privatization in Russia'

13. Pavel Mertlík, Charles University, Prague:

'Production Slump in Czecho-Slovakia: Critical Overview'

14. Ruth M. Mahr, Cornell University, Ithaca: 'Transition in Central Europe: Czecho-Slovak Experience' 
15. Frederic H. Murphy and Susan H. Shaw, Temple University, Philadelphia:

'Natural Gas Deregulation Alternatives: Lessons for Central Europe'

The following papers were also scheduled, but not presented:

16. Jeffrey R. Gates, The Gates Group, Washington, D.C.:

'Community without the Communism'

17. Pavel Berka, University of Waikato, Hamilton, New Zealand:

'The Manufacturing Future of Central Europe'

18. Prof. Robert J. McIntyre, Smith College, Northampton, MA:

'Intermediate Structures and Shock Transition'

19. Milan Zeleny, Fordham University, New York: 'Shock Therapy and Its Failures: Towards Growth-Oriented Alternative'

20. Egon Matzner, Technische Universität, Vienna, Austria:

'An Agenda for Socio-Economic Reconstruction of Central Europe'

The Symposium was organized by Prof. Milan Zeleny of Fordham University. The Discussant was Prof. Stig Rée from the Copenhagen School of Economics, Denmark.

A special issue of Human Systems Management has been organized to publish an edited and representative selection of symposium papers. The contributors are: David Ellerman, Allan Meltzer, Christopher Clague, Jaroslav Vanek, Pavel Mertlík, Robert J. McIntyre and Shann Turnbull.

The S.A.S.E. Conference featured also additional sessions and papers dealing with the issues of economic transformation in Russia and Central Europe, thus providing for the largest gathering of the world's transformation economists, consultants, businessmen and politicians so far. Among the related papers, the following were listed by S.A.S.E.:

1. Juraj Sipko, M.I.T., Cambridge:

'The Transformation Process in Czechoslovakia'
2. David W. Scully, Economic Research Service, Washington, D.C.:

'Dirty Money: Property and Society in Czechoslovakia'

3. John C. Leggett, Rutgers University, Newark: 'Post-Communist Colonialism'

4. Attila Szilassy, Institute East-West Studies, New York:

'What Kind of Democracy in Central Europe?'

5. Gernot Grabher, Wissenschaftzentrum, Berlin: 'The Social Embeddedness of Economic Transformation in Central and Eastern Europe'

6. Peter M.E. Volten, Institute Clingendael, Netherlands:

'Eastern and Central European Transformation'

7. Wlodek Okrasa, Social Science Research Council, New York:

'Household Welfare between 'State' and 'Market': Hardship versus Opportunities during the Economic Transition in Eastern Europe'

8. Christine Rider, St. John's University, New York:

'The Marketization of Eastern Europe: A Sufficient Prerequisite for EC Membership?'

9. Krysztof J. Ners, European Studies Center, Stirín, The Czech Republic:

'Endogeneous Development and/or Western Assistance'

10. Stefan Vogt, Universität Freiburg, Germany: 'Norms, Institutions and the Prospects for Economic Growth in Central and Eastern Europe'

11. Daniel Chirot, University of Washington, Seattle:

'Nationalism, Ideology and Economic Development: Peculiar Contradictions in Eastern Europe'

12. Liah Greenfeld, Harvard University, Cambridge:

'Interests and Passions behind Current Russian Revolution and their Relation to Democracy'

13. Kazimierz Dadek, Fordham University, New York:

'Workers' Incentives in Eastern Europe: SelfManagement vs. Privatization' 
14. Warner Woodworth, Brigham Young University, Salt Lake City:

'Terra Incognita: From Command Economy to Economic Democracy in the CIS'

15. Marguerite Mendell, Concordia University, Montreal:

'Alternative Investment Strategies: The Democratization of Capital in Eastern Europe'

16. I.Y. Bogdanov, Russian Academy of Sciences, Moscow:

'Market and Democracy in the Former Soviet Union'

17. Sally Bould, University of Delaware and Stefka Koeva, Varna, Bulgaria:

'Impact of the Transition to a Market Economy on Women's Employment and Unemployment in Varna, Bulgaria'

18. Magoroh Maruyama, Aoyama Gakuin University, Tokyo:

'Bankruptcy Game and Inactive Savings Game Played by Managers in Hungary: Microgain which Leads to Macroloss'

19. George Liber, University of Alabama, Birmingham:

'Passions, Interests and the Drive for Ukrainian Independence, 1985-1991'

20. Natalia Tsarkova, Harvard University, Cambridge:
'Sermon on the Marketplace: Current Transformation in the Soviet/Russian Cinema'

21. John Hassard, Keele University, Staffor dshire: 'Employee Empowerment or the Enhancement of Exploitation: Total Quality Management and Industry Democracy'

22. Paul R. Lawrence, Harvard Business School, Cambridge:

'Joint Ventures in Russia: Learning from Experience'

23. Peter Rutland, Wesleyan University:

'Czech Labor Unions: From Socialism to Capitalism'

Interested economic researchers and practitioners, wishing to pursue the field of transformation economics within an organized exchange, cooperation and consulting international network, should contact:

Prof. Milan Zeleny,

Graduate School of Business, GBA 626E,

Fordham University at Lincoln Center,

New York, NY 10023, U.S.A.

Fax: + 12127655573

Internet: zeleny@mary.fordham.edu

Bitnet: zeleny@fordmulc.bitnet 